Journal of Urban and Regional Analysis, vol. XIII, 1, 2021, p. 125 - 144

https://doi.org/10.37043/JURA.2021.13.1.8

\title{
EVALUATION OF REGIONAL DEVELOPMENT WITH BANKING AND FINANCE DATA
}

\author{
Bilge MEYDAN, Aydin ULUCAN, Kazim Baris ATICI \\ Hacettepe University, Ankara, Turkey
}

\begin{abstract}
This research aims to measure the change of provincial development levels of Turkey's 81 provinces through banking sector data. The applied methodology is the Malmquist Total Factor Productivity Index (MTFPI). We perform the analysis based on two models. The main difference between models relies on handling the factor associated with 'loans'. The first approach sees the loans as an output factor, which is based on the idea that loans indicate investment and therefore development. In the second model, we take the loans as an input factor, which represents the idea that loans indicate debt and therefore they should be minimized. We evaluate the findings with respect to geographical classification and the province development index.
\end{abstract}

Key Words: regional development, banking system, data envelopment analysis, Malmquist Total Factor Productivity Index.

\section{Introduction}

Measuring regional development levels is important in shaping micro and macro planning. Such measurements can provide insight on what to be prioritized in policies or investments while generating long-term development plans, as well as, it is possible to identify potential allocation areas for the resources and funds in the short-term. Having an idea on the level of financial, intellectual and environmental development at the regional level is beneficial for identifying reference provinces and preparing improvement policies for the undeveloped ones. Accordingly, various research can be found that evaluate the financial, intellectual and environmental aspects of regional development at the provincial level. The studies address a variety of issues, such as: identifying how effective the resources of provinces are used (Giffinger et al. 2007, Ulucan and Atıcı 2010, Giffinger and Haindlmaier 2010, Raźniak et al. 2015); evaluating life quality in order to position the well-being of countries on a provincial basis (Zhu 2001, Morais and Camanho 2011, Carboni and Russu 2015); determining the level of provinces in terms of planning services (Lahdelma et al. 2002, O'Connor 2010); assessing environmental development (Hanson et al. 2011, Sheng and Tang 2016); evaluating intellectual development (López-Ruiz et al. 2014, Nitkiewicz et al. 2014); and the measurement of competitiveness among provinces (Kourtit et al. 2013, Singhal et al. 2013a, Singhal 2013b).

Regional development is highly associated with regional prosperity. For measuring the level of prosperity (therefore development) in a given region, the banking data, as well as the economic indicators, can play a key role since they have the potential to give an idea on the financial structure of the region. Such data can reveal how the money is distributed between deposits and loans, which indirectly provides insight on the financing of the investments within the region. Provincial-level evaluations using economic indicators (such as employment level, tax revenues, imports, exports, size of the manufacturing industry in the given region, etc.) is very common in evaluating regional development levels.

In this research, we aim to incorporate a financial perspective to such evaluations using the banking data of the provinces together with other indicators. The banking data used in this study include different types of loans (personal, sectoral and non-cash sectoral loans) given out 
by the bank branches and deposits (deposits and foreign exchange deposits) in the branches at provincial level. Together with indicators such as employment, participation rate in the labor force, imports, exports and several indicators on investors, we aim to come up with a multidimensional measure of regional development with respect to the economic and financial structure in 81 provinces of Turkey to reflect the level of prosperity as well. The analysis is intending to evaluate the period following the 2008 crisis for which there exists a prevalent claim that the Turkish financial sector has experienced the effects of this crisis less severely than the western economies (Yörükoğlu and Atasoy 2010, Kibritci Artar and Atilgan Saridoğan 2012).

Data Envelopment Analysis (DEA) is a widely used methodology to evaluate relative performance in the presence of multiple dimensions (input and output) in the intended evaluations. It is a non-parametric method applied in both micro and macroeconomic levels since its introduction by Charnes et al. (1978). DEA provides a relative measurement of efficiency for the evaluated units. This is done by comparing the evaluated unit's performance with an efficient frontier using linear programming. In its standard use, the method measures the relative efficiency at a point in time. Because it is a relative measure, the efficiency measured at one point in time is relative to the given period's frontier. When the evaluation period changes, the frontier also changes and, therefore, the efficiency measure in a given period may not be comparable with the next period's measure. Building upon these facts on the DEA measures, the Malmquist Total Factor Productivity Index (MTFPI) has been developed (Caves et al. 1982, Färe et al. 1992) to measure the changes over time by considering both changes in efficiency and the shift on the frontier from one period to another.

Our evaluations intend to involve the handling of multiple indicators as well as multiple periods (2009-2014). Therefore, in measuring the provincial level financial performance, we use DEA and MTFPI to observe the movement of the measures over time. With the use of these methods, the efficiency score of each province and its change over time are measured relative to all other provinces. We interpret the findings relying on the existing measure of the Provincial Development Index (PDI) developed by Gül and Çevik (2015), classifying the provinces of Turkey into 5 clusters relying on their development level. Regarding the model design, we undertake the problem with two main approaches. The main difference between these two approaches relies on handling the factor associated with 'loans'. The first approach sees the loans as an output factor, which relies on the idea that loans indicate investment and therefore development. On the contrary, in the second model, we take the loans as an input factor, which relies on the idea that loans indicate debt and therefore they should be minimized.

The current research evaluates the provincial development levels in Turkey and its change over the years followed by the 2008 crisis, leaning on the idea that banking data can provide additional perspective (regarding prosperity) to the assessment of regional development. Commonly used economic factors are not ignored during evaluations, and instead, banking sector data is articulated into conventional variables, resulting in a comprehensive look at regional development. Inserting new dimensions to the problem enabled us to interpret the provinces' development level from a different angle, by discussing the provincial-level results concerning the current classification regarding development. This provides us to observe how the provinces that are currently identified as developed or underdeveloped perform with respect to the models involving both economic and financial criteria. The results may reveal potential improvement areas and the provinces that require attention in managing regional development. The findings are also interpreted concerning the GDP change during the same period, which reveals a similar pattern in one of the approaches.

The paper is organized as follows: Section 2 presents the basics of the DEA and MTFPI methodologies. Section 3 is devoted to empirical application. We introduce the data set, discuss the model design and present the findings in this section. Finally, Section 4 concludes. 


\section{Methodology}

The Malmquist Total Factor Productivity Index (MTFPI) is a Data Envelopment Analysis (DEA) based approach that allows the efficiency measurement over a certain period (Malmquist 1953, Caves et al. 1982, Färe et al. 1992). MTFPI measures the change in total factor productivity between two data points by calculating the ratios of the differences of each data point relative to the efficient frontiers of production technologies in each period. The distance function is used for the measurement. It is a nonparametric measure of productivity change which also contains information about the source of this change. The index represents the magnitude of improvement (or decrease) in the productivity of the evaluated unit from period $t$ to $t+1$. The calculation of the index relies on the evaluation of the unit in both periods $c$ and $t+1$ followed by cross evaluations of each period's performance within the data of the other period by making use of the fundamental CCR DEA model developed by Charnes et al. (1978). To calculate the MTFPI for each unit, DEA linear programs should be solved.

Let us consider $n$ decision-making units. We assume that each decision-making unit $j$ for $j=1,2, \ldots, n$ uses $m$ different inputs $x_{i j}$. For $i=1,2, \ldots, m$ and it produces $s$ different outputs. $\Upsilon_{j}$ For $r=1,2, \ldots, s$. Let $ø$ represent the efficiency score for unit 0 . Variables $\lambda_{j}$ are introduced corresponding to each decision-making unit $(i=1,2, \ldots, m)$ to form a Production Possibility Set (PPS) consisting of observed units, their convex combinations, scaled units (because the constant returns to scale are assumed) and outperformed units. The units on the boundary (frontier) of the PPS are defined as efficient and they attain the efficiency score of $100 \%$, where the efficiency scores for others are measured relative to the frontier. The linear programming formulation to calculate the efficiency score of unit $o$ is given below:

$$
\begin{array}{ll}
\operatorname{Max} \phi & \\
\text { s.t. } & i=1,2, \ldots, m \\
\sum_{j=1}^{n} \lambda_{j} x_{i j} \leq x_{i 0} & r=1,2, \ldots, s \\
\sum_{j=1}^{n} \lambda_{j} y_{r j} \geq \phi y_{r 0} & j=1,2, \ldots, n \\
\lambda_{j} \geq 0 &
\end{array}
$$

In general, DEA models provide the efficiency measurement at a point in time. Let

$$
D_{o}^{t}\left(x^{t}, y^{t}\right)=\phi
$$

In order to measure the change from one period to another, the MTFPI is calculated for each unit. MTFPI consists of two components as Efficiency Change and Technological Change. Efficiency Change refers to the ratio of efficiency score in period $t+1$ to the efficiency score in period $t$. This measure itself is not enough to identify the change in productivity from one period to another because these scores are relative to different frontiers. Therefore, it is essential to measure the change in the frontier from one period to another. This is the second component of the MTFPI, known as technological change. The calculation of Efficiency Change (EC) and Technological Change (TC) components for a unit are given below: 


$$
\begin{aligned}
& E C=\frac{D_{0}^{s+2}\left(x^{s+2}, y^{5+2}\right)}{D_{0}^{f}\left(x^{s}, y^{5}\right)} \\
& T C=\left[\left(\frac{D_{\delta}^{f}\left(x^{6+2}, y^{5+2}\right)}{D_{\delta}^{\delta+2}\left(x^{5+2}, y^{5+2}\right)}\right) *\left(\frac{D_{\delta}^{f}\left(x^{6}, y^{5}\right)}{D_{\delta}^{\delta+2}\left(x^{6}, y^{9}\right)}\right)\right]^{1 / 2}
\end{aligned}
$$

Once both components are calculated relvina on the linear programs, the MTFPI of a unit is calculated as given below (given as $M_{o}\left(x^{t+1}, y^{t+1}, x^{t}, y^{t}\right)$ to represent the change from period $t$ to $t+1$.

$$
M_{O}\left(x^{t+1}, y^{t+1}, x^{t}, y^{t}\right)=\left[\left(\frac{D_{0}^{t}\left(x^{t+2}, y^{t+2}\right)}{D_{0}^{t}\left(x^{t}, y^{t}\right)}\right)\left(\frac{D_{0}^{t+2}\left(x^{t+2}, y^{t+2}\right)}{D_{0}^{t+2}\left(x^{t}, y^{t}\right)}\right)\right]^{1 / 2}
$$

Data Envelopment Analysis (DEA) and related methodologies such as Malmquist Total Factor Productivity Index (MTFPI) can be counted in the commonly used methods to measure the relative performance of provinces regarding regional development. MTFPI enables the application of DEA in multiple periods. Among the accounted research above, several DEA and its associate methods (e.g. Super Efficiency, Fuzzy DEA, Malmquist Total Factor Productivity Index) have been applied to different types of provincial data to come up with identifying efficiency levels as well as a ranking of the provinces (for examples, see Zhu 2001, Giffinger and Haindlmaier 2010, Ulucan and Atıcı 2010, Morais and Camanho 2011, Kourtit et al. 2013, Nitkiewicz et al. 2014, Carboni and Russu 2015, Wang et al. 2016, Chen 2017, Li et al. 2017, Li et al. 2018, Deilmann et al. 2018, Cao et al. 2019).

Banking is one of the major areas where DEA and MTFPI are also applied (some examples include Paradi and Schaffnit 2004, Thoraneenitiyan and Avkıran 2009, Paradi et al. 2011, PiotLepetit and Nzongang 2014, Alves et al. 2020, Christopoulos et al. 2020). DEA is also used to evaluate the performance of financial institutions (Sufian 2008, Cummins et al. 2010) and micro -finance institutions (Gutiérrez-Nieto et al. 2009, Biener and Eling 2011, Bassem 2014).

\section{Results}

\section{Data}

In measuring the regional development at provincial-level in Turkey, we undertook 16 variables (input and output factors). The set of factors involves economic indicators (such as employment level, tax revenues, imports, exports, size of the manufacturing industry in the given region, etc.) which are very common in evaluating the regional development levels. We benefited from the previous literature while identifying these variables (Atan et al. 2004, Düzakın 2009, LópezRuiz et al. 2014, Nitkiewicz et al. 2014, Piot-Lepetit and Nzongang 2014, Carboni and Russu 2015). Within the scope of the research, we aim to incorporate a financial perspective to the evaluations using the banking data of the provinces together with other indicators. Therefore, the set of factors also includes factors from the banking sector in the provinces of Turkey. All factors used in the study are explained below.

The factors related to the labor force (Turkish Statistical Institute 2016):

- $\quad$ Participation Rate in Labor Force represents the total number of people participating in the labor force in provinces between 2009 and 2014. 
- $\quad$ Employment Rate represents the total number of employees hired in provinces between 2009 and 2014.

The factors related to the manufacturing industry (Turkish Ministry of Science, Industry and Technology).

- $\quad$ Number of Workplaces in Manufacturing Industry refers to the total number of active firms in the period of 2009-2014.

- $\quad$ Net Sales in Manufacturing Industry refers to net sales of firms (in Turkish Liras) by the end of the year between 2009-2014.

The factors related to the banking sector (Banking Regulation and Supervision Agency 2016):

- $\quad$ Personal Loans are cash credits used by individuals. It includes personal finance credit, vehicle loan, commercial personal finance credit, and mortgage loan.

- $\quad$ Sectoral Loans are cash loans provided for small, medium and large-sized commercial enterprises for commercial goods and services purchase as their legal entity.

- Deposits are bank accounts that contain money deposited to withdrawn at any time or the end of a specific term or notice. This variable refers to the sum of all types of deposit accounts (Turkish Lira) in banks of provinces.

- $\quad$ Foreign Exchange Deposit (FED) Account refers to the sum of all foreign exchange deposit accounts in banks of provinces. (Measured in Turkish Lira conversion).

- $\quad$ Total TL+FED refers to the sum of all accounts in banks of provinces (measured in US Dollars).

- Non-Cash Sectoral Loans are bank's credit facility by giving guarantee and bail in favor of legal entities and appropriate credits for the sector of legal entities with the aim that they could sustain their import and export activities. Letter of guarantee, external letter of guarantee and letter of credits are included in this loan group.

The factors related to investment potentials (Central Registry Agency 2016):

- $\quad$ The number of Investors refers to the number of individual investors registered in a certain province and transacting in the stock market.

- $\quad$ Total Account Balance refers to the total account balance amount of individual investors registered in a certain province and transacting in the stock market.

The Factors associated with contribution foreign trade (Turkish Statistical Institute 2016):

- Import represents total annual import activities carried out in provinces (measured in Turkish Liras).

- Export represents total annual export activities carried out in provinces (measured in Turkish Liras).

Other Factors:

- Tax Revenues represent the provincial-based tax revenues (in Turkish Liras). We acquire data from the Turkish Revenue Administration (2016).

- Energy Consumption expresses the total electrical energy consumed throughout a year in provinces as MWh. It measures the total electricity consumption of both industry and household in the provinces. The data source is the Turkish Statistical Institute.

Note that the factors associated with banking cover three main types of banks operating in Turkey: Deposit Banks, Participation Banks (Interest-free banks) and Development \& Investment Banks. All categories include sub-categories as public, private and foreign banks. The data is collected from the database of the Banking Regulation and Supervision Agency of 
Turkey at provincial level for all types.

\section{Findings}

We establish two models in handling the factors listed above. The controversy is related to the factors related to 'loans'. We approach these variables from two perspectives. The first approach looks at the loans as an output factor, which relies on the idea that loans indicate investment and therefore development. On the contrary, in the second model, we capture the loans as input factors, relying on the idea that loans indicate debt and therefore they should be minimized. This means that for loans, we have "the more is better" in one model and "the less is better" in another, respectively. Hence, we consider the factors associated with loans in our models as proxies of investment or indebtment in the given region. Below, we provide the findings of both models.

\section{Model 1: Loans as Outputs}

The model includes 9 outputs and 7 inputs that 81 provinces and the data from 2009-2014 Inputs and outputs used in the analysis are given in Table 1. Scores for each province are presented in Table A1 of the Appendix.

Fig. 1 presents the movement of the Malmquist Total Factor Productivity Index (MTFPI) over years together with its components. The MTFPI moves along with the technological change component in the period of 2009-2014. 2009-2010 is the most progressive period, while the most decrease is observed in the 2011-2012 period. The efficiency change component is more stable, in general. This shows that the changes in MTFPI are mostly caused by the shift in the investment environment (represented by technological change), rather than the individual changes in the financial structure of provinces (that can be embodied by the efficiency change component). Taking 2009 as the base year, the relationship between technological change and MTFPI can also be observed in Table 2. While the efficiency change component decreases

\section{Input and Output Factors for Model 1}

Table 1

\begin{tabular}{|l|l|}
\hline \multicolumn{1}{|c|}{ Inputs } & \multicolumn{1}{c|}{ Outputs } \\
\hline Participation Rate in Labor Force & Personal Loans \\
\hline Employment Rate & Sectoral Loans \\
\hline Number of Workplace in Manufacturing Industry & Deposits (Turkish Lira) \\
\hline Net Profit In Manufacturing Industry & Deposits (Foreign Exchange) \\
\hline Import & Total Deposits \\
\hline Export & Non-Cash Sector Loans \\
\hline Energy Consumption & Tax Revenues \\
\hline & The Number of Investors \\
\hline & Total Account Balance \\
\hline
\end{tabular}

with the rate of $1 \%$ between the years of 2009-2014, the technological change component increases by $76 \%$, resulting in a $75.4 \%$ increase in total productivity.

Since it is observed that technological change is dominant in increasing the total productivity, it is reasonable to observe its relationship with the GDP growth in the country over the given period. Fig. 2 presents the GDP Increase with MTFP. Generally, the GDP increase rate of 


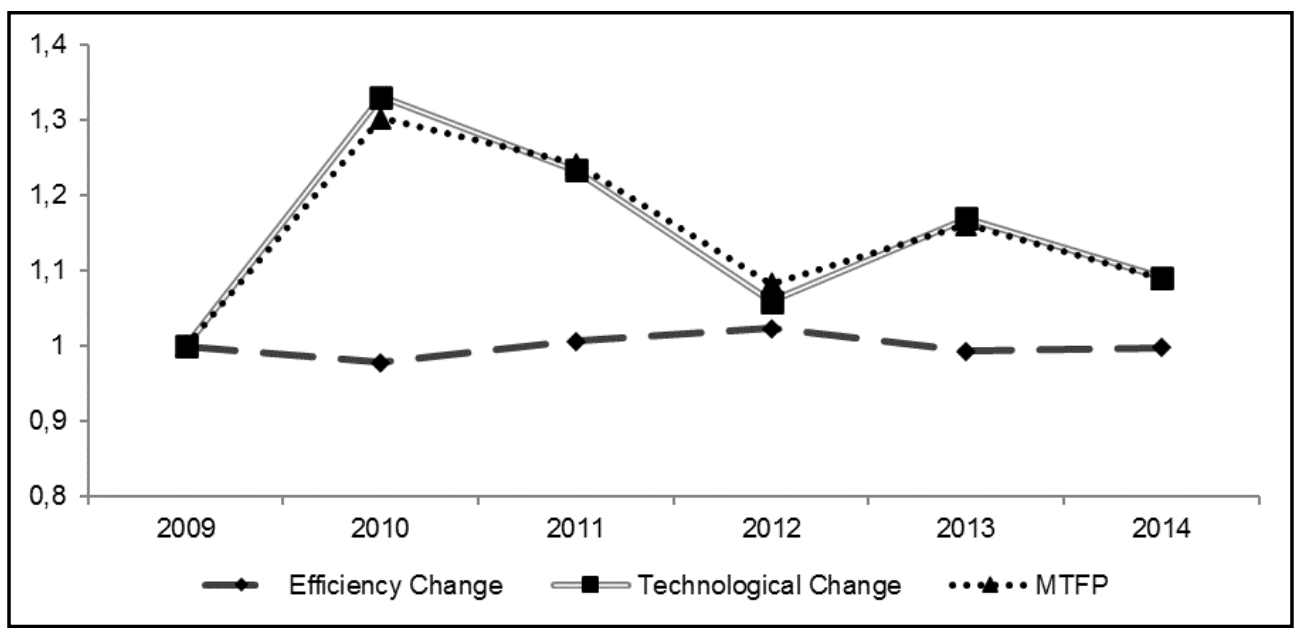

Fig. 1 - MTFP Change by Year (Model 1)

Turkey and the total factor productivity change seem to be parallel with each other. This is a sign that economic growth over the given period has a reflection on local development.

Fig. 3 shows the change in total factor productivity based on PDI. The results are interesting. Between 2002 and 2014, category 5, which consists of the least developed provinces, exhibit the largest progress. Category 4 has also experienced growth between 2010 and 2011. The

\section{Change in Cumulative Efficiency by Years (Model 1)}

Table 2

\begin{tabular}{|c|c|c|c|}
\hline Years & Efficiency Change & $\begin{array}{c}\text { Technological } \\
\text { Change }\end{array}$ & $\begin{array}{c}\text { Total Factor } \\
\text { Productivity }\end{array}$ \\
\hline 2009 & 1 & 1 & 1 \\
\hline 2010 & 0.978 & 1.331 & 1.302 \\
\hline 2011 & 0.984 & 1.642 & 1.617 \\
\hline 2012 & 1.006 & 1.739 & 1.751 \\
\hline 2013 & 0.999 & 2.033 & 2.033 \\
\hline 2014 & 0.997 & 2.218 & 2.214 \\
\hline Geometric Mean & $\mathbf{0 . 9 9 3}$ & $\mathbf{1 . 7 6 5}$ & $\mathbf{1 . 7 5 4}$ \\
\hline
\end{tabular}

least progress is observed in the most developed category. These findings may indicate that the growth in the post-crisis period seems to be deployed at different levels throughout the country. It is observed that the categories with the least developed provinces (category 4 and category 5) experience a noticeable growth relative to the other categories.

\section{Model 2: Loans as Inputs}

The model includes 6 outputs and 10 inputs of 81 provinces and the data from 2009-2014. The inputs and outputs used in the analysis are given in Table 4 . The scores for each province are presented in Table A2 of the Appendix. 
Fig. 4 presents the movement of the Malmquist Total Factor Productivity Index (MTFPI) over the years based on Model 2 together with its components. The largest fluctuation has been

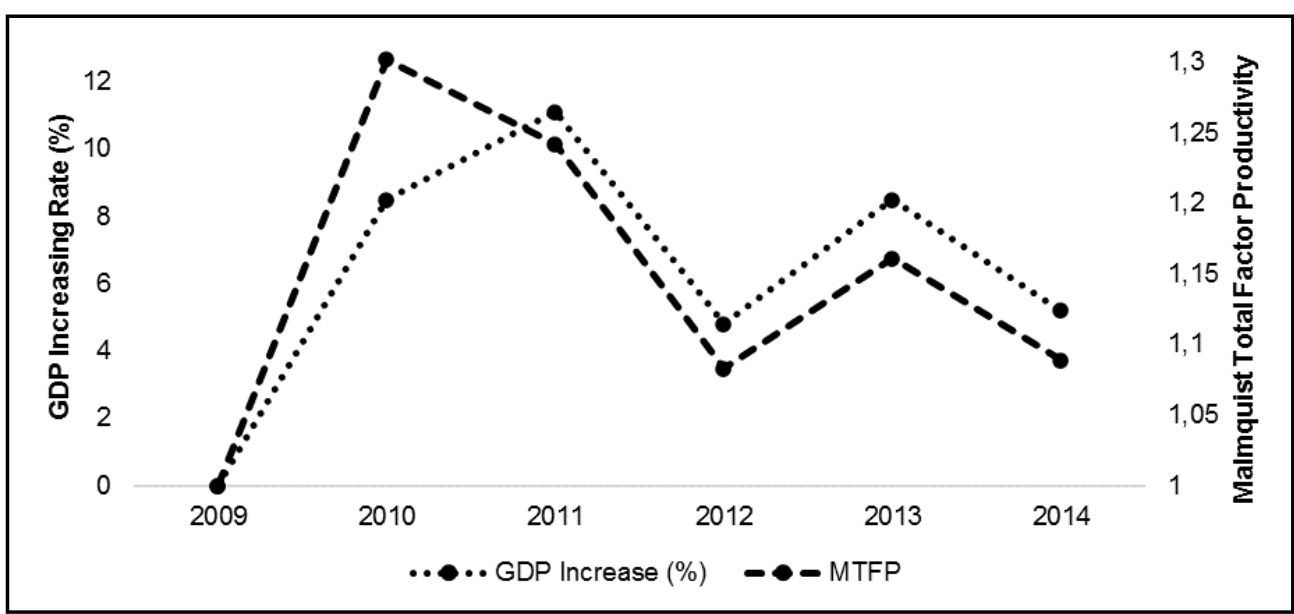

Fig. 2 - GDP Growth Rate and Comparative MTFPI Chart (Model 1)

Province Classification of PDI

Table 3

\begin{tabular}{|l|c|c|c|c|c|}
\hline & Category 1 & Category 2 & Category 3 & Category 4 & Category 5 \\
\hline \# of Provinces & 6 & 17 & 27 & 14 & 17 \\
\hline
\end{tabular}

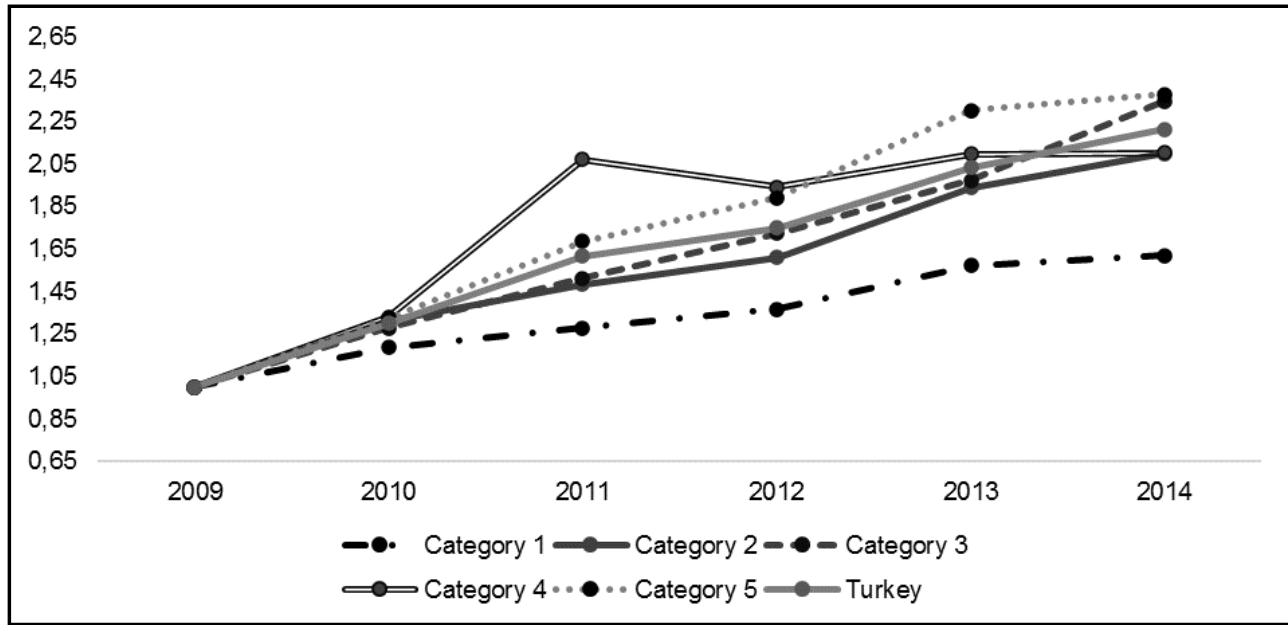

Fig. 3 - Total Factor Productivity Change by PDI (Model 1) 
observed between the years 2009-2011. In this model, MTFPI also moves along with the technological change rather than the efficiency change. The directions are opposite with the Model 1 findings since the factors have changed sides.

Table 5 reveals the MTFPI over the years and it indicates a decrease in terms of total

Input and Output Factors for Model 2

Table 4

\begin{tabular}{|l|l|}
\hline \multicolumn{1}{|c|}{ Inputs } & Outputs \\
\hline Participation Rate in Labor Force & Deposit (Turkish Lira) \\
\hline Employment Rate & Deposit (Foreign Exchange) \\
\hline $\begin{array}{l}\text { Number of Workplace in Manufacturing In- } \\
\text { dustry }\end{array}$ & Total Deposit \\
\hline Net Profit in Manufacturing Industry & Tax Revenues \\
\cline { 1 - 1 } Personal Loans & $\begin{array}{c}\text { Number Of Registered Investor to } \\
\text { Stock Market }\end{array}$ \\
\cline { 1 - 1 } Sectoral Loans & Total Amount Of Account Balance \\
\hline Non-Cash Sector Loans & \\
\hline Energy Consumption & \\
\hline Import & \\
\hline Export & \\
\hline
\end{tabular}

productivity caused by technological change. By looking at the results in Table 2 and Table 5 together, it is possible to say that the direction of productivity depends on the treatment of loans. If loans are input factors, then there is a decline in the total productivity and vice versa. Model 2 results can also be interpreted in terms of PDI. Fig. 5 presents the movement of MTFPI with respect to different categories. Every category experiences a decrease except for

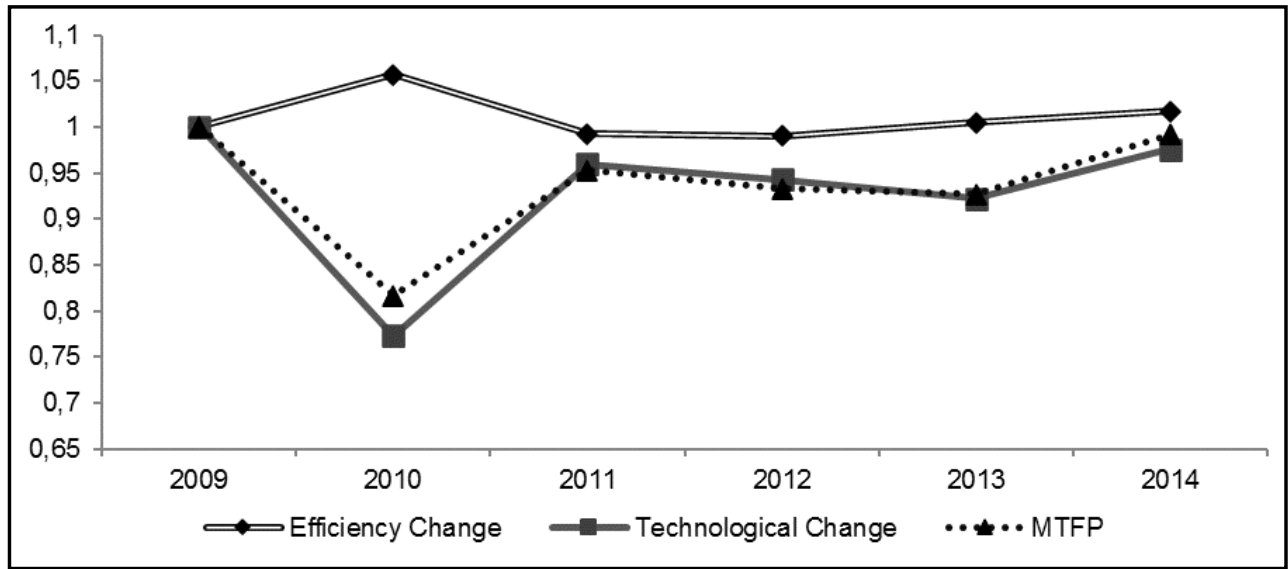

Fig. 4 - Chart of MTFP by years (Model 2) 
category 4 between 2010 and 2011 (none of the MTFPI values are over 1 except for that one) Categories 1, 2, 3 and 5 follow mainly a stationary movement over the years. For category 4, there is a spike in 2011 , followed by a relatively slower growth.

Change in the Cumulative Efficiency by year (Model 2)

Table 5

\begin{tabular}{|c|c|c|c|}
\hline Years & Efficiency Change & Technological Change & MTFPI \\
\hline 2009 & 1 & 1 & 1 \\
\hline 2010 & 1.057 & 0.773 & 0.817 \\
\hline 2011 & 1.050 & 0.742 & 0.779 \\
\hline 2012 & 1.039 & 0.700 & 0.726 \\
\hline 2013 & 1.044 & 0.645 & 0.673 \\
\hline 2014 & 1.062 & 0.630 & 0.668 \\
\hline
\end{tabular}

Discussion

The findings presented in the previous section indicate that if the factors related to loans (personal loans, sectoral loans, and non-cash loans) are treated as outputs, growth in productivity is observed. Treating 'loans' as an output factor yields scores that are more closely

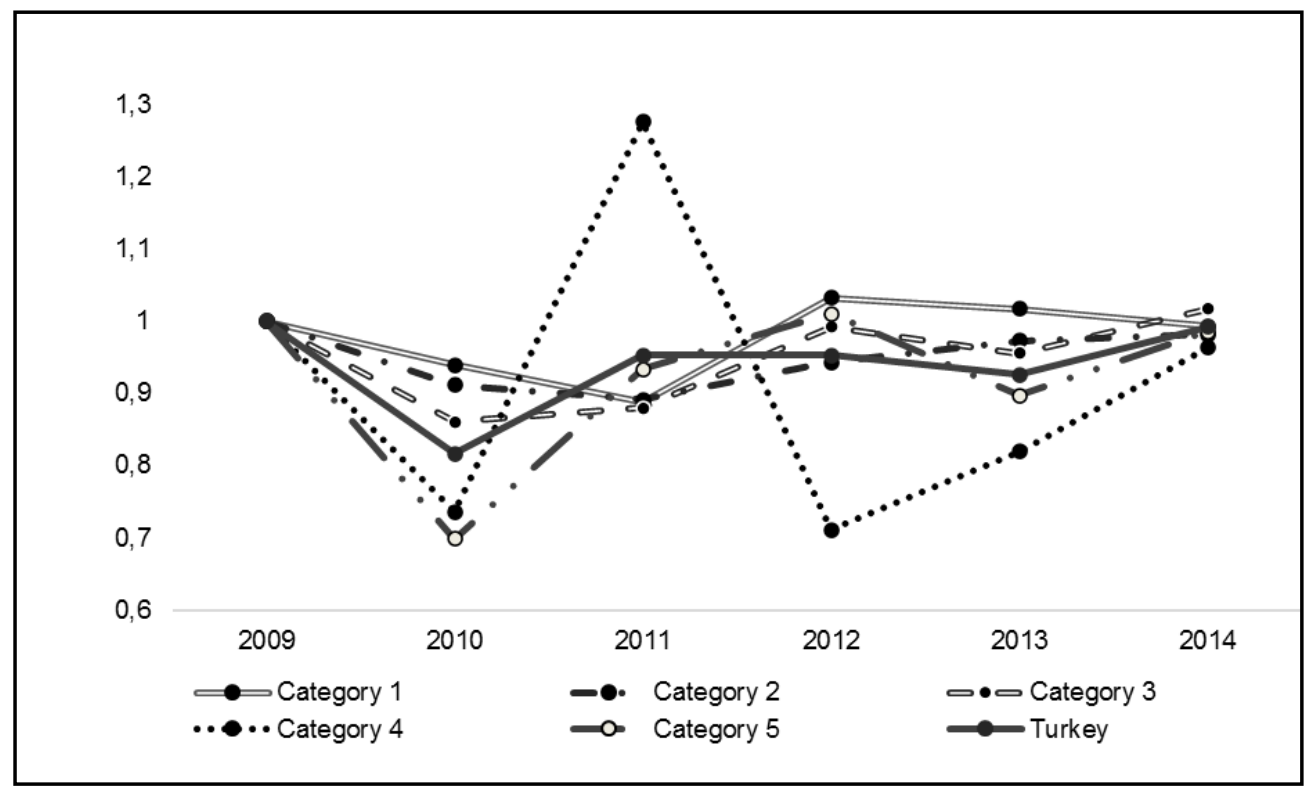

Fig. 5 - Total Factor Productivity Change by PDI (Model 2)

related to the GDP growth of Turkey during the given period. Fig. 6 visualizes the MTFPI scores of Model 1 at provincial level. It is noticeable that the eastern parts of the country experience a larger growth relative to the west. Some provinces attain a very high level of change (greater than 4), mostly located in the east. The east mostly consists of category 4 and 5 provinces; however, these provinces experience the largest growth according to Model 1. 
Note that Model 1 considers 'loans' as outputs. We approach the factors associated with loans as a proxy of investment in this model. Of course, one should note that the analysis does not solely rely on the variables associated with loans. There are other financial outputs and also an input side of the story. We have variables on employment, the size of the manufacturing industry, etc. These will also differ between high-income and low-income provinces. Nevertheless, the Data Envelopment Analysis is about accounting for such trade-offs through the multi-dimensional relativity of output/input ratios. From that perspective, in the post-crisis period, there had been an expansion in the financial system at regional level, especially for less developed provinces according to Model 1. If loans indicate investment, then there had been a growth in regional development for the less developed regions after the 2008 crisis.

On the other hand, loans can be thought of as the proxy of indebtment as in Model 2. Fig. 7 visualizes the MTFPI scores of Model 2 at provincial level. It is observed that the majority of the provinces exhibit a decrease. When Fig. 6 and Fig. 7 are compared, it can be seen that only a few of the provinces could keep their productivity growth position. One province experiences a

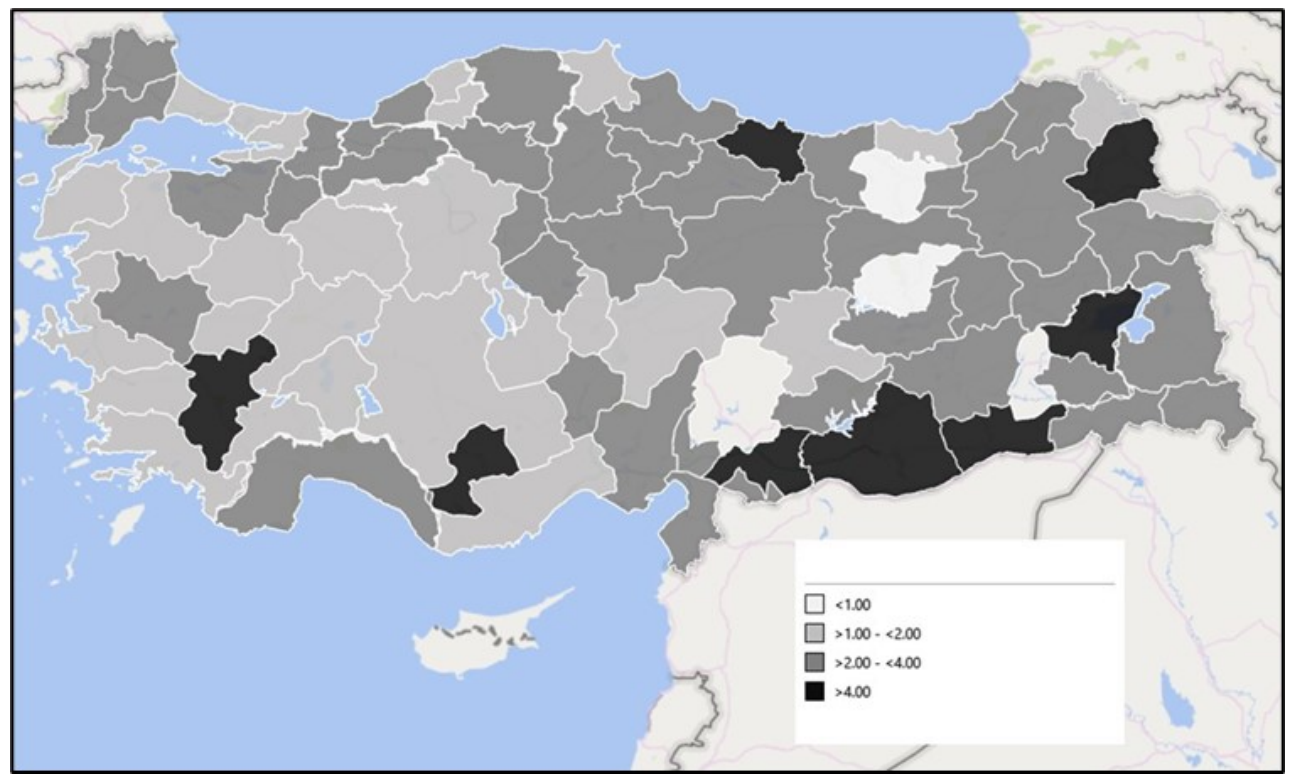

Fig. 6 - Provinces by their MTFPI Scores (Model 1)

high level of growth and only 10 provinces attain a score greater than 1 . So, when the factors associated with loans are taken as inputs, the development levels of the provinces concerning banking and finance data reveal a decrease in all categories of provinces. This, of course, contradicts with the GDP growth during the given period. Note that loans include the cash and non-cash sectorial loans. If loans indicate debt, then there had been a decline in regional development for the entire country after the 2008 crisis. One advocating loans as a means of debt would think that the decrease in the development levels in the post-crisis period is based on recovering the effects of the recession during the crisis, which would be reasonable. The contradictions between the results of the two models reveal that the idea of growth is mainly affected by depending on the opinion towards the 'loans' provided by the banks. 
It should also be noted that the technological change component is more effective in the change of MTFPI. The change mostly relies on the shifts on the frontier, in other words, the technological change component. Rather than individual changes in the scores (corresponding to the efficiency change component) of individual units (provinces in our case), the growth, or decline mostly, is mainly based on the shift of the frontier as a whole. In other words, from whichever perspective we approach the problem, the effects of the crisis are visible throughout the entire sample rather than the small changes at unit level.

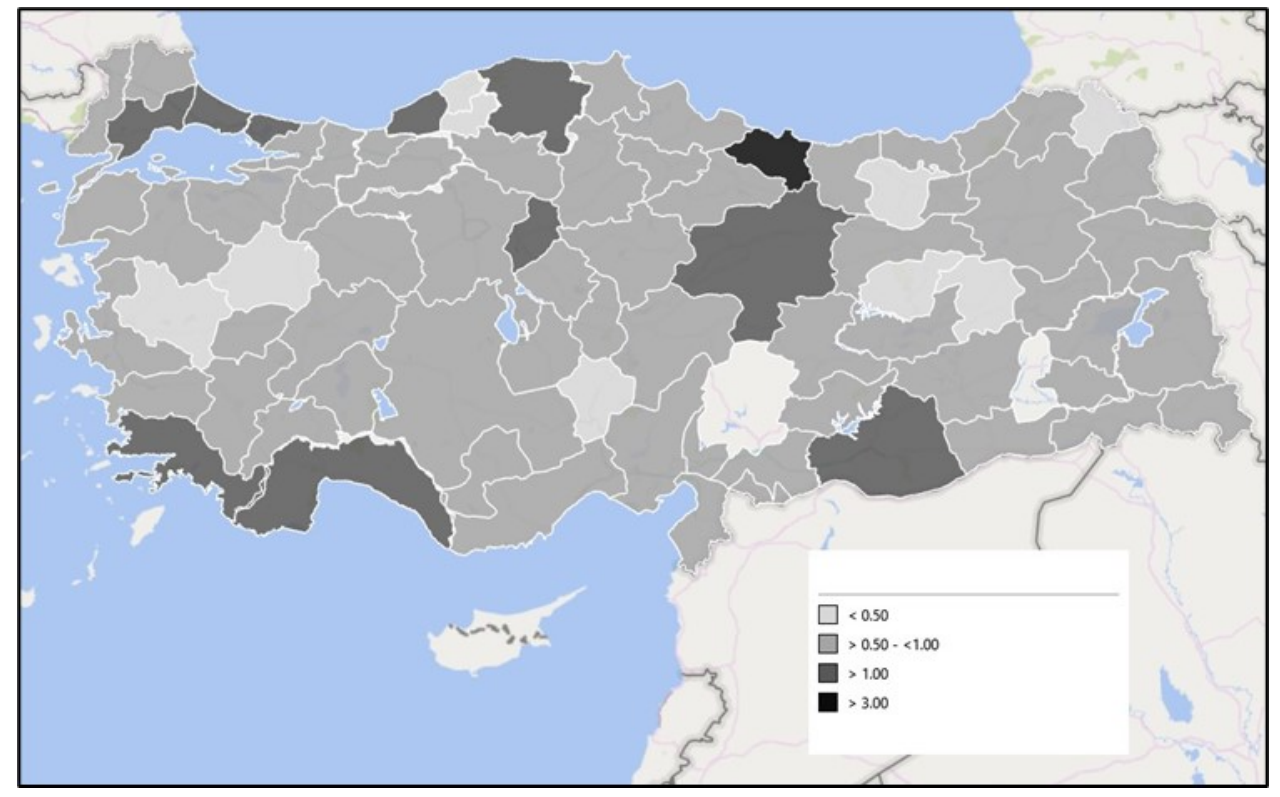

Fig. 7 - Provinces by their MTFPI Scores (Model 2)

\section{Conclusions}

In this paper, we aim to measure the provincial level financial performance of Turkish provinces using banking and finance data along with other economic indicators. For this purpose, we develop two Data Envelopment Analysis (DEA) models, mainly differing from each other in terms of handling the factors associated with 'loans', which turns out to affect the results when the direction of those variables is changed. The methodology is based on relativity and multidimensionality so that a broad perspective on regional development is aimed to be presented. As well as being a non-parametric efficiency evaluation method, DEA can also serve as an effective tool for a relative assessment in measuring regional development levels. Besides, we use a multi-period structure and the Malmquist Total Factor Productivity Index (MTFPI) method is employed to measure the change in 5 years after the 2008 crisis (between 2009 and 2014). The index is composed of two main components, namely as efficiency change and as technological change. The former represents the changes in the efficiency of individual units, whereas the latter is based on the shift in the production technology as a whole. The results are interpreted with respect to cumulative changes and to provincial development index categories. The results presented at cumulative and provincial level categories may reveal potential improvement areas and the provinces that require attention in managing regional development.

We evaluate the provincial development levels in Turkey and its change over the years, leaning 
on the idea that banking data can provide an additional perspective to the assessment of regional development. Considering the banks' key role in the financial system, the evaluations fed by the banking perspective along with the macroeconomic indicators can contribute to the way we approach regional development. The use of DEA in a mix of economic and financial/ banking indicators conveys a new perspective to the assessment. Of course, banking data requires careful handling since different perspectives may lead to different directions as exposed by the findings of this research.

\section{References}

ALVES A. B., WANKE P., ANTUNES J., CHEN Z. (2020), Endogenous Network Efficiency, Macroeconomy, and Competition: Evidence from the Portuguese Banking Industry, The North American Journal of Economics and Finance 52, 101114.

ATAN M., ÖZGÜR E., GÜLER H. (2004), Comparison of Developmental Levels of Provinces by Multivariate Statistical Analysis and DEA, Gazi University Journal of Faculty of Economics and Administrative Sciences 6 (2), 25-42.

BANKING REGULATION AND SUPERVISION AGENCY (2016), FinTürk, Retrieved from: www.bddk.org.tr.

BASSEM B. S. (2014), Total Factor Productivity Change of MENA Microfinance Institutions: A Malmquist Productivity Index Approach, Economic Modelling 39, 182-189.

BIENER C., ELING M. (2011), The Performance of Microinsurance Programs: A Data Envelopment Analysis, The Journal of Risk and Insurance 78 (1), 83-115.

CAO L., ZHOU Z., WU Y., HUANG Y., CAO G. (2019), Is metabolism in all regions of China performing well? - Evidence from a new DEA-Malmquist productivity approach, Ecological Indicators 106, 105487.

CARBONI O. A., RUSSU P. (2015), Assessing Regional Wellbeing in Italy: An Application of Malmquist-DEA and Self-organizing Map Neural Clustering, Social Indicators Research 122, 677-700.

CAVES D. W., CHRISTENSEN L. R., DIEWERT W. E. (1982), The Economic Theory of Index Numbers and the Measurement of Input, Output, and Productivity, Econometrica 50 (6), 1393-1414.

www.mkk.com.tr.

CENTRAL REGISTRY AGENCY (2016), CSD of Turkey, Retrieved from:

CHARNES A., COOPER W. W., RHODES E. (1978), Measuring the Efficiency of Decision Making Units, European Journal of Operational Research 2 (6), 429-444.

CHEN C. C. (2017), Measuring departmental and overall regional performance: applying the multi-activity DEA model to Taiwan's cities/counties, Omega 67, 60-80.

CHRISTOPOULOS A. G., DOKAS I. G., KATSIMARDOU S., SPYROMITROS E. (2020), Assessing banking sectors' efficiency of financially troubled Eurozone countries, Research in International Business and Finance 52, 101121.

CUMMINS J. D., WEISS M. A., XIE X., ZI H. (2010), Economies of Scope in Financial Services: A DEA Efficiency Analysis of the US Insurance Industry, Journal of Banking \& Finance 34 (7), 1525-1539.

DEILMANN C., HENNERSDORF J., LEHMANN I., REIßMANN D. (2018), Data envelopment analysis of urban efficiency-Interpretative methods to make DEA a heuristic tool, Ecological Indicators 84, 607-618.

DÜZAKIN H. (2009), Measuring the Province Performances With DEA, Journal of Cukurova University Faculty of Economics and Administrative Sciences 13 (2), 17-32.

FÄRE R., GROSSKOPF S., LINDGREN B., ROOS P. (1992), Productivity Changes in Swedish Pharamacies 1980-1989: A non-parametric Malmquist approach, Journal of Productivity Analysis 3, 85-101.

GIFFINGER R., FERTNER C., KRAMAR H., MEIJERS E. (2007), City-ranking of European Medium-Sized Cities, European Smart Cities, Retrieved from: www.smart-cities.eu. 
GIFFINGER R., HAINDLMAIER G. (2010), Smart Cities Ranking: An Effective Instrument for the Positioning Of Cities?, ACE: Architecture, City and Environment 4 (12), 7-25. GÜL H. E., ÇEVIK B. (2015), Development Level Research of Cities in Turkey with the Data of 2013, I Türkiye İş Bankası İktisadi Araştırmalar Bölümü, pp. 1-27.

GUTIERREZ-NIETO B., SERRANO-CINCA C., MOLINERO C. M. (2009), Social Efficiency in Microfinance Institutions, Journal of the Operational Research Society 60 (1), 104119.

HANSON S., NICHOLLS R., RANGER N., HALLEGATE S., CORFEE-MORLOT J., HERWEIJER C., CHATEAU J. (2011), A global ranking of port cities with high exposure to climate extremes, Climatic Change 104, 89-111.

KIBRITCI ARTAR O., ATILGAN SARIDOĞAN A. (2012), The Effects of the Global Financial Crisis on the Financial Structure of the Banking Sector in the Turkish Economy, The Journal of Marmara Social Research 2, 1-17.

KOURTIT K., NIJKAMP P., SUZUKI S. (2013), The Rat Race Between World Cities: In Search of Exceptional Places by Means of Super-efficient Data Development Analysis, Computers, Environment and Urban Systems 38, 67-77.

LAHDELMA R., SALMINEN P., HOKKANEN J. (2002), Locating a Waste Treatment Facility by Using Stochastic Multicriteria Acceptability Analysis with Ordinal Criteria, European Journal of Operational Research 142 (2), 345-356.

LI L.-B., LIU B.-L., LIU W.-L., CHIU Y.-H. (2017), Efficiency evaluation of the regional high-tech industry in China: A new framework based on meta-frontier dynamic DEA analysis, Socio-Economic Planning Sciences 60, 24-33.

LI N., JIANG Y., MU H., YU Z. (2018), Efficiency evaluation and improvement potential for the Chinese agricultural sector at the provincial level based on data envelopment analysis (DEA), Energy 164, 1145-1160.

LÓPEZ-RUIZ V.-R., ALFARO-NAVARRO J.-L., NEVADO-PEÑA D. (2014), Knowledgecity Index Construction: An Intellectual Capital Perspective, Expert Systems with Applications 41 (12), 5560-5572.

MALMQUIST S. (1953), Index Numbers and Indifference Surfaces, Trabajos de Estadistica 4, 209-242.

MORAIS P., CAMANHO A. S. (2011), Evaluation of Performance of European Cities with the Aim to Promote Quality of Life Improvements, Omega 39 (4), 398-409.

NITKIEWICZ T., PACHURA P., REID N. (2014), An Appraisal of Regional Intellectual Capital Performance Using Data Envelopment Analysis, Applied Geography 53, 246-257. O'CONNOR K. (2010), Global City Regions and the Location of Logistics Activity, Journal of Transport Geography 18 (3), 354-362.

PARADI J. C., SCHAFFNIT C. (2004), Commercial Branch Performance Evaluation and

Results Communication in a Canadian Bank-a DEA Application, European Journal of Operational Research 156 (3), 719-735.

PARADI J. C., ROUATT S., ZHU H. (2011), Two-stage Evaluation of Bank Branch Efficiency Using Data Envelopment Analysis, Omega 39 (1), 99-109.

PIOT-LEPETIT I., NZONGANG J. (2014), Financial Sustainability and Poverty Outreach within a Network of Village Banks in Cameroon: A Multi-DEA Approach, European Journal of Operational Research 234 (1), 319-330.

RAŻNIAK P., WINIARCZYK-RAŻNIAK A., NOWOTNIK D. (2015), Central and Eastern

European Cities in Globalized World, Socio-Economic Problems and the State 12 (1), 22-33. SHENG N., TANG U. W. (2016), The First Official City Ranking by Air Quality in China

- A Review and Analysis, Cities 51, 139-149. SINGHAL S., MCGREAL S., BERRY J. (2013a), Application of a Hierarchical Model for

City Competitiveness in Cities of India, Cities 31, 114-122. SINGHAL S., MCGREAL S., BERRY J. (2013b), An Evaluative Model for City Competitiveness: Application to UK Cities, Land Use Policy 30 (1), 214-222.

SUFIAN F. (2008), The Efficiency of Non-Bank Financial Intermediaries: Empirical 
Evidence from Malaysia, The International Journal of Banking and Finance 5 (2), 149-167. THORANEENITIYAN N., AVKIRAN N. K. (2009), Measuring the Impact of Restructuring and Country-Specific Factors on the Efficiency of Post-Crisis East Asian Banking Systems: Integrating DEA with SFA, Socio-Economic Planning Sciences 43 (4), 240-252.

TURKISH REVENUE ADMINISTRATION (2016), Budget Revenues, Retrieved from: www.gib.gov.tr.

TURKISH STATISTICAL INSTITUTE (2016), Socio-economic data, Retrieved from: www.tuik.gov.tr.

ULUCAN A., ATICI K. B. (2010), Efficiency Evaluations with Context-dependent and Measure-specific Data Envelopment Approaches: An Application in a World Bank Supported Project, Omega 38 (1-2), 68-83.

WANG J., ZHAO T., ZHANG X. (2016), Environmental assessment and investment strategies of provincial industrial sector in China - Analysis based on DEA model, Environmental Impact Assessment Review 60, 156-168.

YÖRÜKOGLU M., ATASOY H. (2010), The effects of the global financial crisis on the Turkish financial sector, BIS Papers 54, 387-405.

ZHU J. (2001), Multidimensional Quality-of-life Measure with an Application to Fortune's Best Cities, Socio-Economic Planning Sciences 35 (4), 263-284.

Initial submission: 14.10.2019

Revised submission: 13.04 .2020

Final acceptance: 29.05 .2020

Correspondence: Hacettepe University, Üniversiteler, Hacettepe Beytepe Kampüsü, 06800 Çankaya, Ankara, Turkey.

Email: bilgem@hacettepe.edu.tr 


\begin{tabular}{|c|c|c|c|c|c|c|c|c|}
\hline \multicolumn{9}{|c|}{$\begin{array}{c}\text { Appendix } \\
\text { Table A1 }\end{array}$} \\
\hline Rank & Provinces & $\begin{array}{c}\text { Efficiency } \\
\text { Change }\end{array}$ & Rank & Provinces & $\begin{array}{l}\text { Technological } \\
\text { Change }\end{array}$ & Rank & Provinces & $\begin{array}{c}\text { MTFP } \\
1 \\
\end{array}$ \\
\hline 1 & Şanlıurfa & 1.815 & 1 & Ordu & 5.898 & 1 & Şanlıurfa & 8.292 \\
\hline 2 & Muş & 1.411 & 2 & Bitlis & 4.783 & 2 & Ordu & 7.558 \\
\hline 3 & Ordu & 1.282 & 3 & Kars & 4.713 & 3 & Bitlis & 5.631 \\
\hline 4 & Ağrı & 1.276 & 4 & Şanlıurfa & 4.573 & 4 & Kars & 4.713 \\
\hline 5 & Bursa & 1.270 & 5 & Yozgat & 4.035 & 5 & Mardin & 4.478 \\
\hline 6 & Denizli & 1.235 & 6 & Kilis & 3.809 & 6 & Karaman & 4.433 \\
\hline 7 & Erzurum & 1.216 & 7 & K.maraş & 3.772 & 7 & Gaziantep & 4.369 \\
\hline 8 & Karaman & 1.211 & 8 & Mardin & 3.763 & 8 & K.Maraș & 4.351 \\
\hline 9 & Tekirdağ & 1.205 & 9 & Gaziantep & 3.679 & 9 & Denizli & 4.318 \\
\hline 10 & Mardin & 1.189 & 10 & Karaman & 3.660 & 10 & Hatay & 3.848 \\
\hline 11 & Gaziantep & 1.189 & 11 & Hatay & 3.654 & 11 & Muş & 3.639 \\
\hline 12 & Bitlis & 1.177 & 12 & Denizli & 3.499 & 12 & Yozgat & 3.458 \\
\hline 13 & K. Maraş & 1.154 & 13 & Erzincan & 3.499 & 13 & Elazığ & 3.370 \\
\hline 14 & Düzce & 1.133 & 14 & Tokat & 3.492 & 14 & Siirt & 3.284 \\
\hline 15 & İzmir & 1.129 & 15 & Osmaniye & 3.408 & 15 & Sivas & 3.237 \\
\hline 16 & Sakarya & 1.098 & 16 & Elazığ & 3.370 & 16 & Kilis & 3.164 \\
\hline 17 & Hakkari & 1.089 & 17 & Siirt & 3.285 & 17 & Bilecik & 3.039 \\
\hline 18 & Bilecik & 1.067 & 18 & Amasya & 3.093 & 18 & Erzincan & 3.019 \\
\hline 19 & Samsun & 1.061 & 19 & Sivas & 3.085 & 19 & Kırıkkale & 2.910 \\
\hline 20 & Zonguldak & 1.059 & 20 & Giresun & 3.028 & 20 & Osmaniye & 2.890 \\
\hline 21 & Hatay & 1.053 & 21 & Çankırı & 2.965 & 21 & Düzce & 2.835 \\
\hline 22 & Sivas & 1.048 & 22 & Kırıkkale & 2.910 & 22 & Amasya & 2.762 \\
\hline 23 & Balıkesir & 1.045 & 23 & Bilecik & 2.849 & 23 & Erzurum & 2.718 \\
\hline 24 & Manisa & 1.010 & 24 & Çorum & 2.785 & 24 & Samsun & 2.689 \\
\hline 25 & Aksaray & 1.000 & 25 & Kastamonu & 2.768 & 25 & Tokat & 2.673 \\
\hline 26 & Ankara & 1.000 & 26 & Van & 2.741 & 26 & Kastamonu & 2.643 \\
\hline 27 & Antalya & 1.000 & 27 & Adıyaman & 2.711 & 27 & Tekirdağ & 2.632 \\
\hline 28 & Ardahan & 1.000 & 28 & Muș & 2.577 & 28 & Şırnak & 2.479 \\
\hline 29 & Artvin & 1.000 & 29 & Şırnak & 2.574 & 29 & Bingöl & 2.476 \\
\hline 30 & Batman & 1.000 & 30 & Bingöl & 2.544 & 30 & Bursa & 2.465 \\
\hline 31 & Bayburt & 1.000 & 31 & Samsun & 2.538 & 31 & Sakarya & 2.463 \\
\hline 32 & Edirne & 1.000 & 32 & Diyarbakır & 2.531 & 32 & Batman & 2.429 \\
\hline 33 & Elazığ & 1.000 & 33 & Düzce & 2.501 & 33 & Edirne & 2.419 \\
\hline 34 & Eskişehir & 1.000 & 34 & Adana & 2.445 & 34 & Zonguldak & 2.413 \\
\hline 35 & Iğdır & 1.000 & 35 & Malatya & 2.442 & 35 & Adana & 2.410 \\
\hline 36 & İstanbul & 1.000 & 36 & Batman & 2.429 & 36 & Çankırı & 2.400 \\
\hline 37 & Karabük & 1.000 & 37 & Edirne & 2.419 & 37 & Diyarbakır & 2.391 \\
\hline 38 & Kars & 1.000 & 38 & Niğde & 2.391 & 38 & Hakkari & 2.383 \\
\hline 39 & Kırıkkale & 1.000 & 39 & Bolu & 2.367 & 39 & Giresun & 2.361 \\
\hline 40 & Kırklareli & 1.000 & 40 & Rize & 2.349 & 40 & Rize & 2.349 \\
\hline
\end{tabular}




\begin{tabular}{|c|c|c|c|c|c|c|c|c|}
\hline \multirow{2}{*}{\multicolumn{9}{|c|}{ Rankina Cumulative Efficiency Chanae of Provinces }} \\
\hline & & & & & & & & \\
\hline Rank & Provinces & $\begin{array}{c}\text { Efficiency } \\
\text { Change }\end{array}$ & Rank & Provinces & $\begin{array}{l}\text { Technological } \\
\text { Change }\end{array}$ & Rank & Provinces & $\begin{array}{c}\text { MTFF } \\
\text { I }\end{array}$ \\
\hline 41 & Kırşehir & 1.000 & 41 & Bayburt & 2.318 & 41 & Bayburt & 2.318 \\
\hline 42 & Kocaeli & 1.000 & 42 & Zonguldak & 2.279 & 42 & Adıyaman & 2.289 \\
\hline 43 & Mersin & 1.000 & 43 & Kırklareli & 2.250 & 43 & Manisa & 2.260 \\
\hline 44 & Muğla & 1.000 & 44 & Sakarya & 2.242 & 44 & Kirklareli & 2.250 \\
\hline 45 & Nevșehir & 1.000 & 45 & Erzurum & 2.236 & 45 & Ağrı & 2.233 \\
\hline 46 & Rize & 1.000 & 46 & Manisa & 2.232 & 46 & Niğde & 2.195 \\
\hline 47 & Trabzon & 1.000 & 47 & Kayseri & 2.214 & 47 & Çorum & 2.185 \\
\hline 48 & Tunceli & 1.000 & 48 & Hakkari & 2.185 & 48 & Antalya & 2.131 \\
\hline 49 & Yalova & 1.000 & 49 & Tekirdağ & 2.184 & 49 & Kırşehir & 2.097 \\
\hline 50 & Gümüșhane & 1.000 & 50 & Antalya & 2.131 & 50 & Bolu & 2.058 \\
\hline 51 & Siirt & 0.999 & 51 & Sinop & 2.119 & 51 & Artvin & 2.027 \\
\hline 52 & Isparta & 0.997 & 52 & Kırşehir & 2.097 & 52 & Van & 2.002 \\
\hline 53 & Burdur & 0.996 & 53 & Bartin & 2.066 & 53 & Nevşehir & 1.994 \\
\hline 54 & Adana & 0.986 & 54 & Afyonkarahisar & 2.034 & 54 & Trabzon & 1.993 \\
\hline 55 & Ușak & 0.982 & 55 & Artvin & 2.027 & 55 & Kayseri & 1.949 \\
\hline 56 & Bingöl & 0.972 & 56 & Nevşehir & 1.994 & 56 & Malatya & 1.911 \\
\hline 57 & Şırnak & 0.962 & 57 & Trabzon & 1.993 & 57 & Burdur & 1.897 \\
\hline 58 & Çanakkale & 0.958 & 58 & Bursa & 1.941 & 58 & Iğdır & 1.884 \\
\hline 59 & Kastamonu & 0.956 & 59 & Burdur & 1.902 & 59 & Yalova & 1.862 \\
\hline 60 & Diyarbakır & 0.946 & 60 & Iğdır & 1.884 & 60 & Bartın & 1.828 \\
\hline 61 & Aydın & 0.940 & 61 & Yalova & 1.862 & 61 & Karabük & 1.800 \\
\hline 62 & Niğde & 0.917 & 62 & Kütahya & 1.814 & 62 & Sinop & 1.793 \\
\hline 63 & Amasya & 0.893 & 63 & Karabük & 1.800 & 63 & Eskişehir & 1.734 \\
\hline 64 & Konya & 0.891 & 64 & Ağrı & 1.748 & 64 & Çanakkale & 1.586 \\
\hline 65 & Bartin & 0.886 & 65 & Eskişehir & 1.734 & 65 & Kütahya & 1.575 \\
\hline 66 & Kayseri & 0.880 & 66 & Çanakkale & 1.653 & 66 & Aksaray & 1.558 \\
\hline 67 & Bolu & 0.869 & 67 & Aksaray & 1.558 & 67 & Ardahan & 1.550 \\
\hline 68 & Kütahya & 0.868 & 68 & Ardahan & 1.550 & 68 & İstanbul & 1.507 \\
\hline 69 & Erzincan & 0.861 & 69 & Aydın & 1.537 & 69 & Uşak & 1.492 \\
\hline 70 & Yozgat & 0.857 & 70 & Konya & 1.525 & 70 & Muğla & 1.467 \\
\hline 71 & Osmaniye & 0.848 & 71 & Ușak & 1.519 & 71 & Kocaeli & 1.466 \\
\hline 72 & Sinop & 0.847 & 72 & İstanbul & 1.507 & 72 & Afyonkarahisar & 1.454 \\
\hline 73 & Adıyaman & 0.844 & 73 & Muğla & 1.467 & 73 & Aydın & 1.447 \\
\hline 74 & Kilis & 0.830 & 74 & Kocaeli & 1.466 & 74 & Ankara & 1.366 \\
\hline 75 & Çankırı & 0.810 & 75 & Ankara & 1.366 & 75 & Konya & 1.355 \\
\hline 76 & Çorum & 0.784 & 76 & Isparta & 1.237 & 76 & Isparta & 1.235 \\
\hline 77 & Malatya & 0.783 & 77 & Mersin & 1.230 & 77 & Mersin & 1.230 \\
\hline 78 & Giresun & 0.779 & 78 & Ballkesir & 1.121 & 78 & Balıkesir & 1.172 \\
\hline 79 & Tokat & 0.766 & 79 & İmir & 1.012 & 79 & Izmir & 1.144 \\
\hline 80 & Van & 0.730 & 80 & Gümüşhane & 0.297 & 80 & Gümüșhane & 0.297 \\
\hline 81 & Afyonkarahisar & 0.716 & 81 & Tunceli & 0.109 & 81 & Tunceli & 0.109 \\
\hline
\end{tabular}


Bilge MEYDAN, Aydin ULUCAN, Kazim Baris ATICI

Model 2: Ranking Cumulative Efficiency Change of Provinces

Table A2

\begin{tabular}{|c|c|c|c|c|c|c|c|c|}
\hline Ranking & Provinces & $\begin{array}{c}\begin{array}{c}\text { Efficiency } \\
\text { Change }\end{array} \\
\end{array}$ & Ranking & Provinces & $\begin{array}{c}\text { Technological } \\
\text { Change }\end{array}$ & Ranking & Provinces & MTFPI \\
\hline 1 & Ordu & 1.835 & 1 & Ordu & 1.961 & 1 & Ordu & 3.597 \\
\hline 2 & Șanlıurfa & 1.633 & 2 & Kırıkkale & 1.424 & 2 & Kırıkkale & 1.424 \\
\hline 3 & Kastamonu & 1.484 & 3 & Antalya & 1.219 & 3 & Antalya & 1.312 \\
\hline 4 & Tekirdağ & 1.417 & 4 & Sivas & 1.142 & 4 & Sivas & 1.238 \\
\hline 5 & Sakarya & 1.361 & 5 & Kırklareli & 1.055 & 5 & Şanlıurfa & 1.076 \\
\hline 6 & Bitlis & 1.343 & 6 & Kayseri & 1.045 & 6 & Kastamonu & 1.067 \\
\hline 7 & Kars & 1.283 & 7 & İstanbul & 1.040 & 7 & Zonguldak & 1.048 \\
\hline 8 & Kütahya & 1.251 & 8 & Muğla & 1.034 & 8 & İstanbul & 1.040 \\
\hline 9 & Yozgat & 1.220 & 9 & Kırşehir & 0.993 & 9 & Muğla & 1.034 \\
\hline 10 & Samsun & 1.217 & 10 & Zonguldak & 0.991 & 10 & Tekirdağ & 1.032 \\
\hline 11 & Bilecik & 1.192 & 11 & Ankara & 0.948 & 11 & Kırşehir & 0.993 \\
\hline 12 & Çankırı & 1.183 & 12 & Yalova & 0.940 & 12 & Kayseri & 0.977 \\
\hline 13 & Tokat & 1.178 & 13 & Nevşehir & 0.933 & 13 & Kırklareli & 0.963 \\
\hline 14 & Adiyaman & 1.167 & 14 & Diyarbakır & 0.933 & 14 & Ankara & 0.948 \\
\hline 15 & Burdur & 1.129 & 15 & Mersin & 0.907 & 15 & Yalova & 0.940 \\
\hline 16 & Elazığ & 1.126 & 16 & Trabzon & 0.858 & 16 & Yozgat & 0.935 \\
\hline 17 & Karaman & 1.124 & 17 & Eskişehir & 0.857 & 17 & Nevşehir & 0.933 \\
\hline 18 & Bayburt & 1.114 & 18 & Rize & 0.851 & 18 & Karaman & 0.923 \\
\hline 19 & Manisa & 1.113 & 19 & Karaman & 0.820 & 19 & Trabzon & 0.917 \\
\hline 20 & Erzincan & 1.102 & 20 & Hatay & 0.813 & 20 & Mersin & 0.907 \\
\hline 21 & Balıkesir & 1.097 & 21 & Edirne & 0.808 & 21 & Elazığ & 0.889 \\
\hline 22 & Sivas & 1.085 & 22 & Iğdır & 0.808 & 22 & Rize & 0.851 \\
\hline 23 & Erzurum & 1.077 & 23 & İzmir & 0.799 & 23 & Edirne & 0.847 \\
\hline 24 & Antalya & 1.074 & 24 & Elazığ & 0.789 & 24 & Hatay & 0.846 \\
\hline 25 & Trabzon & 1.069 & 25 & Aksaray & 0.780 & 25 & Iğdır & 0.837 \\
\hline 26 & Amasya & 1.067 & 26 & Erzurum & 0.774 & 26 & Diyarbakır & 0.836 \\
\hline 27 & Düzce & 1.065 & 27 & Yozgat & 0.766 & 27 & Erzurum & 0.834 \\
\hline 28 & Osmaniye & 1.064 & 28 & Giresun & 0.736 & 28 & Eskişehir & 0.818 \\
\hline 29 & Zonguldak & 1.056 & 29 & Bayburt & 0.733 & 29 & Bayburt & 0.816 \\
\hline 30 & Edirne & 1.048 & 30 & Tekirdağ & 0.727 & 30 & İzmir & 0.799 \\
\hline 31 & Hatay & 1.041 & 31 & Kastamonu & 0.718 & 31 & Bitlis & 0.790 \\
\hline 32 & Çorum & 1.037 & 32 & Artvin & 0.716 & 32 & Erzincan & 0.787 \\
\hline 33 & Iğdır & 1.036 & 33 & Erzincan & 0.715 & 33 & Tokat & 0.785 \\
\hline 34 & Aydın & 1.035 & 34 & Çorum & 0.715 & 34 & Aksaray & 0.780 \\
\hline 35 & Batman & 1.035 & 35 & Balıkesir & 0.709 & 35 & Balıkesir & 0.779 \\
\hline 36 & Ağrı & 1.035 & 36 & Amasya & 0.702 & 36 & Amasya & 0.749 \\
\hline 37 & Niğde & 1.033 & 37 & Siirt & 0.700 & 37 & Kars & 0.746 \\
\hline 38 & Afyon & 1.022 & 38 & Gaziantep & 0.699 & 38 & Çorum & 0.741 \\
\hline 39 & Sinop & 1.014 & 39 & K.Maraş & 0.697 & 39 & Samsun & 0.740 \\
\hline 40 & Bartın & 1.005 & 40 & Kocaeli & 0.689 & 40 & Giresun & 0.720 \\
\hline
\end{tabular}


Evaluation of Regional Development with Banking and Finance Data

Model 2: Ranking Cumulative Efficiency Change of Provinces

Table A2

\begin{tabular}{|c|c|c|c|c|c|c|c|c|}
\hline Ranking & Provinces & $\begin{array}{c}\text { Efficiency } \\
\text { Change }\end{array}$ & Ranking & Provinces & $\begin{array}{c}\text { Technological } \\
\text { Change }\end{array}$ & Ranking & Provinces & MTFPI \\
\hline 41 & Bolu & 1.002 & 41 & Çanakkale & 0.672 & 41 & Artvin & 0.716 \\
\hline 42 & Van & 1.001 & 42 & Tokat & 0.667 & 42 & Siirt & 0.700 \\
\hline 43 & Muş & 1.001 & 43 & Şanlıurfa & 0.659 & 43 & Kocaeli & 0.689 \\
\hline 44 & Yalova & 1.001 & 44 & Adana & 0.645 & 44 & K.Maraş & 0.678 \\
\hline 45 & Aksaray & 1.000 & 45 & Ușak & 0.636 & 45 & Çanakkale & 0.672 \\
\hline 46 & Ankara & 1.000 & 46 & Aydın & 0.623 & 46 & Gaziantep & 0.658 \\
\hline 47 & Ardahan & 1.000 & 47 & Denizli & 0.623 & 47 & Aydın & 0.645 \\
\hline 48 & Artvin & 1.000 & 48 & Bursa & 0.616 & 48 & Adana & 0.638 \\
\hline 49 & Bingöl & 1.000 & 49 & Samsun & 0.608 & 49 & Ușak & 0.636 \\
\hline 50 & Çanakkale & 1.000 & 50 & Mardin & 0.603 & 50 & Burdur & 0.621 \\
\hline 51 & Gümüşhane & 1.000 & 51 & Hakkari & 0.600 & 51 & Sakarya & 0.618 \\
\hline 52 & Hakkari & 1.000 & 52 & Bitlis & 0.590 & 52 & Bursa & 0.616 \\
\hline 53 & Isparta & 1.000 & 53 & Kars & 0.581 & 53 & Hakkari & 0.600 \\
\hline 54 & İstanbul & 1.000 & 54 & Van & 0.574 & 54 & Düzce & 0.593 \\
\hline 55 & İzmir & 1.000 & 55 & Şırnak & 0.569 & 55 & Van & 0.574 \\
\hline 56 & Karabük & 1.000 & 56 & Muş & 0.562 & 56 & Batman & 0.574 \\
\hline 57 & Kırıkkale & 1.000 & 57 & Düzce & 0.556 & 57 & Ağrı & 0.572 \\
\hline 58 & Kırşehir & 1.000 & 58 & Batman & 0.556 & 58 & Adıyaman & 0.571 \\
\hline 59 & Kocaeli & 1.000 & 59 & Ağrı & 0.553 & 59 & Şırnak & 0.569 \\
\hline 60 & Mersin & 1.000 & 60 & Bolu & 0.551 & 60 & Muş & 0.562 \\
\hline 61 & Muğla & 1.000 & 61 & Burdur & 0.550 & 61 & Afyon & 0.557 \\
\hline 62 & Nevşehir & 1.000 & 62 & Malatya & 0.549 & 62 & Bolu & 0.552 \\
\hline 63 & Rize & 1.000 & 63 & Afyon & 0.546 & 63 & Malatya & 0.548 \\
\hline 64 & Siirt & 1.000 & 64 & Isparta & 0.542 & 64 & Denizli & 0.547 \\
\hline 65 & Șırnak & 1.000 & 65 & Konya & 0.531 & 65 & Isparta & 0.542 \\
\hline 66 & Tunceli & 1.000 & 66 & Kilis & 0.506 & 66 & Çankırı & 0.541 \\
\hline 67 & Uşak & 1.000 & 67 & Sinop & 0.500 & 67 & Mardin & 0.526 \\
\hline 68 & Malatya & 0.999 & 68 & Adıyaman & 0.489 & 68 & Bilecik & 0.519 \\
\hline 69 & Bursa & 0.998 & 69 & Ardahan & 0.489 & 69 & Konya & 0.509 \\
\hline 70 & Kilis & 0.996 & 70 & Osmaniye & 0.477 & 70 & Osmaniye & 0.507 \\
\hline 71 & Adana & 0.990 & 71 & Bingöl & 0.474 & 71 & Sinop & 0.507 \\
\hline 72 & Giresun & 0.981 & 72 & Çankırı & 0.457 & 72 & Kilis & 0.504 \\
\hline 73 & K.Maraș & 0.972 & 73 & Sakarya & 0.453 & 73 & Ardahan & 0.489 \\
\hline 74 & Konya & 0.958 & 74 & Bilecik & 0.435 & 74 & Kütahya & 0.488 \\
\hline 75 & Eskişehir & 0.955 & 75 & Manisa & 0.431 & 75 & Manisa & 0.479 \\
\hline 76 & Gaziantep & 0.943 & 76 & Niğde & 0.413 & 76 & Bingöl & 0.474 \\
\hline 77 & Kayseri & 0.935 & 77 & Bartın & 0.399 & 77 & Niğde & 0.427 \\
\hline 78 & Kırklareli & 0.913 & 78 & Kütahya & 0.390 & 78 & Bartın & 0.401 \\
\hline 79 & Diyarbakır & 0.897 & 79 & Karabük & 0.384 & 79 & Karabük & 0.384 \\
\hline 80 & Denizli & 0.879 & 80 & Gümüşhane & 0.165 & 80 & $\begin{array}{l}\text { Gümüşhan } \\
\text { e }\end{array}$ & 0.165 \\
\hline 81 & Mardin & 0.871 & 81 & Tunceli & 0.004 & 81 & Tunceli & 0.004 \\
\hline
\end{tabular}


Province Classes in PDI

\begin{tabular}{|c|l|}
\hline Categories & \multicolumn{1}{|c|}{ Provinces } \\
\hline Category 1 & Ankara, Antalya, Bursa, İstanbul, İzmir, Kocaeli \\
\hline Category 2 & $\begin{array}{l}\text { Adana, Aydın, Balıkesir, Çanakkale, Denizli, Eskişehir, Gaziantep, Hatay, } \\
\text { Kayseri, Konya, Manisa, Mersin, Muğla, Sakarya, Samsun, Tekirdağ, } \\
\text { Trabzon }\end{array}$ \\
\hline Category 3 & $\begin{array}{l}\text { Afyonkarahisar, Amasya, Bartın, Bilecik, Bolu, Burdur, Çorum, Diyarbakır, } \\
\text { Düzce, Edirne, Elazığ, Erzurum, Isparta, K. Maraş, Karabük, Karaman, } \\
\text { Kırıkkale, Kırklareli, Kütahya, Malatya, Nevşehir, Rize, Sivas, Şanlıurfa, } \\
\text { Uşak, Yalova, Zonguldak }\end{array}$ \\
\hline Category 4 & $\begin{array}{l}\text { Aksaray, Artvin, Çankırı, Erzincan, Giresun, Kastamonu, Kırşehir, Mardin, } \\
\text { Niğde, Ordu, Osmaniye, Sinop, Tokat, Tunceli }\end{array}$ \\
\hline Category 5 & $\begin{array}{l}\text { Adıyaman, Ağrı, Ardahan, Batman, Bayburt, Bingöl, Bitlis, Gümüşhane, } \\
\text { Hakkari, lğdır, Kars, Kilis, Muş, Siirt, Şırnak, Van, Yozgat }\end{array}$ \\
\hline
\end{tabular}

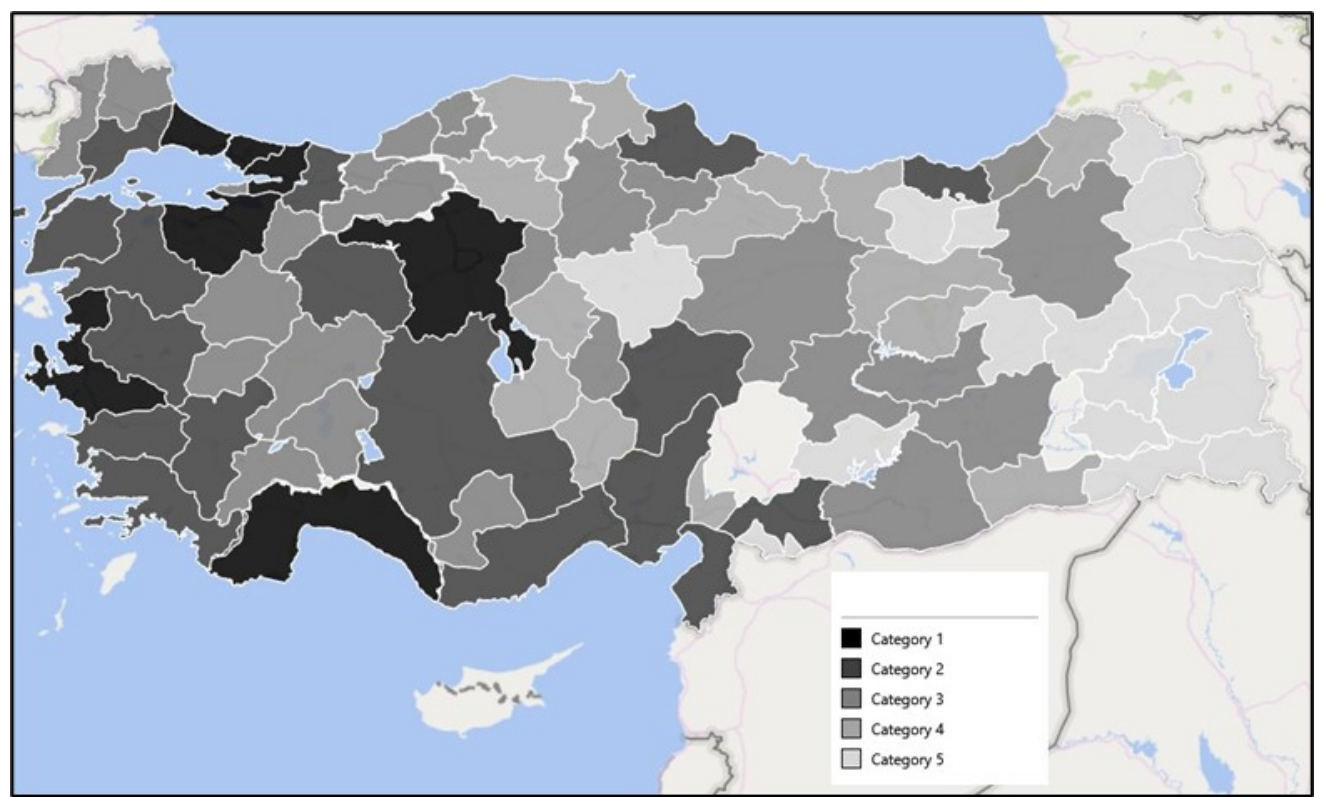

Fig. A1-Classified Provinces of Turkey 